\title{
Acute enteritis: dehydration and rehydration in pediatric patients
}

\author{
Piera Dones \\ From 70th Congress of the Italian Society of Pediatrics, Joint National Meeting SIP, SICuPP, SITIP \\ Palermo, Italy. 11-14 June 2014
}

Acute infectious enteritises are widespread globally. In developing countries, they are one of the leading causes of infant mortality. In developed countries, they account for a high number of outpatient visits and hospitalizations, with an economic impact on national health systems and, considering indirect costs, on communities. In roughly $70 \%$ of cases, the infections are caused by viral agents, principally rotavirus. A study conducted in collaboration with the Regional Referral Center for the Monitoring of Rotavirus Infection found that the serotypes isolated in all rotovirus-positive samples in the province of Palermo were $68 \% \mathrm{G} 1 \mathrm{P} 8$, and in $12.9 \%$ G2P4. In $20 \%$ of the cases, infectious gastroenteritis was caused by bacterial agents. At our hospital, the prevalent agents are salmonella spp. and campylobacter. For viral infections, there are no epidemiologic differences between developed countries and developing countries, though in the latter there is a higher mortality rate, associated with more difficult access to health care, malnutrition, and underlying diseases. Rehydration is first line treatment for pediatric enteritis. Indications for parenteral rehydration are generally quite restricted, and reserved for cases of severe dehydration, or cases in which oral rehydration solutions cannot be given either because of uncontrollable vomiting or because they cannot sufficiently restore electrolytes. A recent meta-analysis published in Pediatrics found that hypotonic pediatric solutions are the most widely used in hospitalized children. Use of these low-sodium solutions can lead to hyponatremia. Therefore, pediatric patients should always be rehydrated with isotonic solutions (0.9\% NSS). For patients with hyponatremia, treatment should be slowly extended over a period of 24 hours, and sodium gradually supplemented in relation to total body water in order to avoid pontine myelinolysis, which is most frequent in dehydrated patients with severe underlying

Pediatric Infective Diseases U.O.C., G. Di Cristina Hospital, Palermo, Italy disease. However, it has also been found in otherwise healthy patients in whom treatment of hyponatremia was administered too rapidly. In fact, too rapid treatment can also lead to cerebral edema and/or seizures. Treatment should, in fact, be administered gradually over a period of 48-72 hours. Hypernatremic patients with hypovolemia clear more free water than solutes, so the total concentration of corporeal sodium is likely lower than that found in testing; therefore, treatment should also include isotonic fluids.

Published: 11 August 2014

doi:10.1186/1824-7288-40-S1-A59

Cite this article as: Dones: Acute enteritis: dehydration and rehydration

in pediatric patients. Italian Journal of Pediatrics 2014 40(Suppl 1):A59.

\begin{abstract}
Submit your next manuscript to BioMed Central and take full advantage of:

- Convenient online submission

- Thorough peer review

- No space constraints or color figure charges

- Immediate publication on acceptance

- Inclusion in PubMed, CAS, Scopus and Google Scholar

- Research which is freely available for redistribution

() Biomed Central

C 2014 Dones; licensee BioMed Central Ltd. This is an Open Access article distributed under the terms of the Creative Commons Attribution License (http://creativecommons.org/licenses/by/4.0), which permits unrestricted use, distribution, and reproduction in any medium, provided the original work is properly cited. The Creative Commons Public Domain Dedication waiver (http:// creativecommons.org/publicdomain/zero/1.0/) applies to the data made available in this article, unless otherwise stated. 